\title{
Kanak Identity, New Citizenship Building and Reconciliation
}

Isabelle Leblic

\section{Q OpenEdition \\ 1 Journals}

\section{Electronic version}

URL: http://journals.openedition.org/jso/1004

DOI: $10.4000 /$ jso. 1004

ISSN: $1760-7256$

\section{Publisher}

Société des océanistes

\section{Printed version}

Date of publication: 1 December 2007

Number of pages: 271-282

ISBN: 978-2-85430-010-9

ISSN: 0300-953x

\section{Electronic reference}

Isabelle Leblic, "Kanak Identity, New Citizenship Building and Reconciliation », Journal de la Société des Océanistes [Online], 125 | Année 2007-2, Online since 01 December 2010, connection on 21 April 2019. URL : http://journals.openedition.org/jso/1004 ; DOI : 10.4000/jso.1004 


\title{
Kanak Identity, New Citizenship Building and Reconciliation ${ }^{1}$
}

by

\author{
Isabelle LEBLIC*
}

Abstract

2004-2005 is the twentieth anniversary of the November 1984-January 1985 events which have greatly stigmatized the politics and the social life in New Caledonia. The Noumea Accord (may 1998) introduced the idea of new citizenship for the people living in New Caledonia. On which foundation could it be built, without denying Kanak identity yet taking into account the various populations who lived in New Caledonia before 1988? In July 2004, 15 years after the drama of Ouvea, where JeanMarie Tjibaou and Yeiwéné Yeiwéné were killed (May 4, 1989), Kanaks from Maré, Ouvéa and Hienghène met without any political organization for a great reconciliation. These facts will be analyzed for a better understanding of the what is actually at stake for the future New Caledonia.

KEYwords: kanak Identity, Noumea accord, citizenship, New Caledonia

\section{RÉSUMÉ}

2004-2005 est le vingtième anniversaire des événements de novembre 1984 à janvier 1985 qui ont marqué profondément la Nouvelle-Calédonie et sa vie politique et sociale. L'accord de Nouméa (de mai 1998) a introduit la notion d'une nouvelle citoyenneté et l'on peut se demander sur quelle base celle-ci va pouvoir se construire, sans nier l'identité Kanak mais en prenant en compte également les autres composantes présentes depuis longtemps sur le territoire. Dernièrement, en juillet 2004, les Kanak de Maré, d'Ouvéa et de Hienghène se sont retrouvés, en dehors de toute organisation politique, pour une grande réconciliation, suite à l'assassinat à Ouvéa de Jean-Marie Tjibaou et de Yeiwéné Yeiwéné le 4 mai 1989. Voilà quelques données qu’il nous faut analyser pour comprendre les enjeux de la Nouvelle-Calédonie de demain.

Mots-CLÉs: identité kanak, accord de Nouméa, citoyenneté, Nouvelle-Calédonie

«And to be Âji Âboro, Dö Kâmo or "truly a human being", is also to be ready to share with the others, yesterday "victims of history" 2 " and tomorrow citizens of our country. [...] on our way to citizenship [...], "the future must be time of identity, in a unanimous destiny".» (Déwé Gorodé ${ }^{3}$, Nouméa, Tjibaou culturel Centre, $1^{\text {st }}$ december 2004)

«Going back to the tradition is a myth; [...] no one has experienced it. The search for identity, the model, for me, is in front of me, never behind. It is a constant reformulation. And I shall say that our present struggle is to be able to put forward the best of our past, our culture, to build the model of man and society that we want for the edification of the citizenship. [...] our identity is in front of us.» (Jean-Marie Tjibaou, $1985: 1601)$

1. A version of this text was pronounced at Marseille at the $6^{\text {th }}$ Conference of the European Society for Oceanists (July 6-8, 2005).

2. Since the meeting of Nainvilles-les-Roches (July1983), which gathered, for the aim of reconciliating communities of territory, representatives of the RPCR, the FNSC and the FI, the FI (prefigurating the FLNKS). They spoke about the «victims of history» to designate people born in the territory whose parents (at least one) had been born there too.

3. Vice-president of the government of New-Caledonia, in charge of Culture, Feminization and Citizenship; excerpt from the opening speech of the CORAIL symposium 2004: Lieux communs et représentations dans le Pacifique insulaire (Nouméa, $1^{\text {st }}-3^{\text {rd }}$ December 2004).

*Ethnologue, uMR CNRS 7107- LACITO, à Villejuif, leblic@vjf.cnrs.fr 


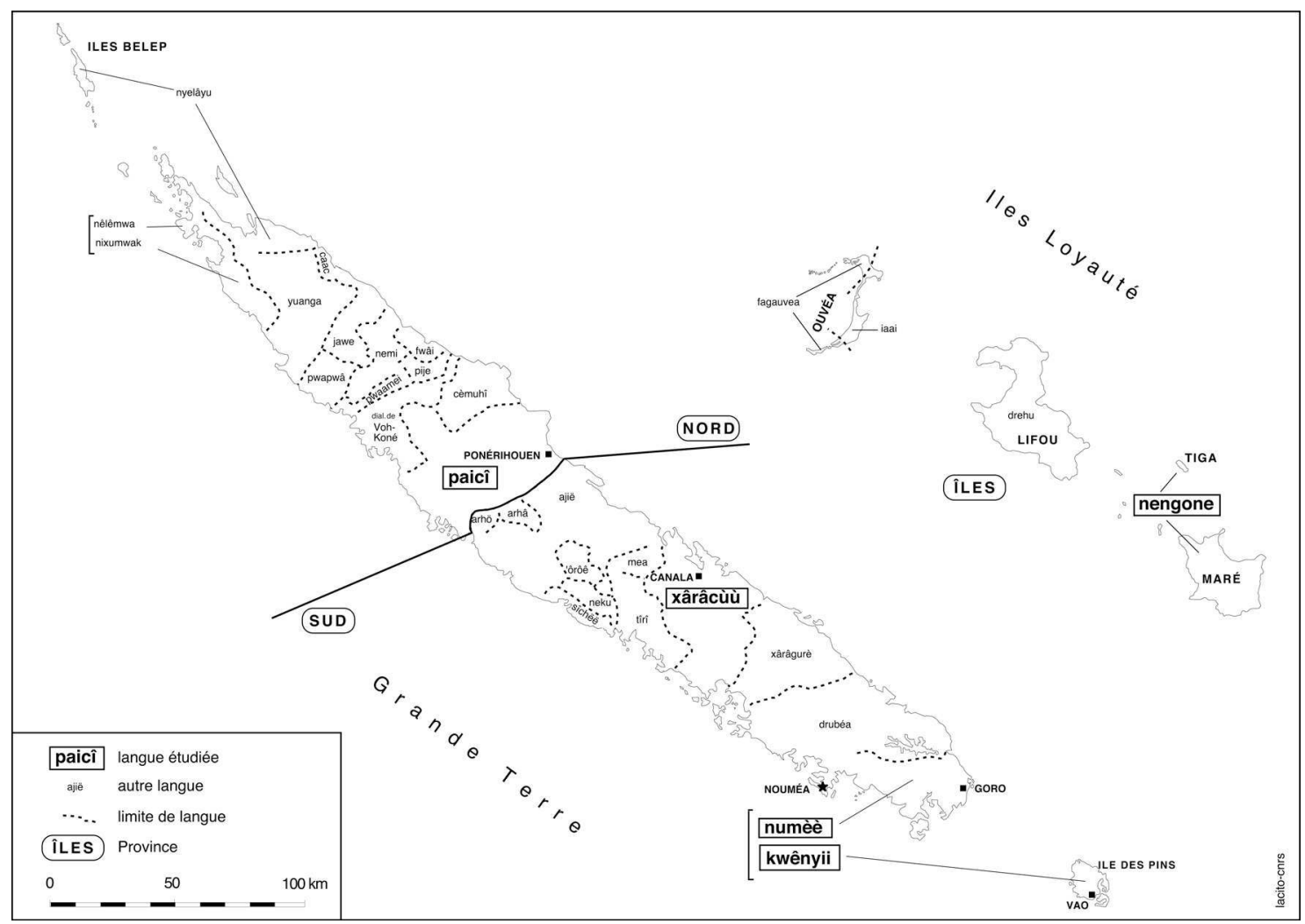

Map 1. - New Caledonia

What is actually at stake for the future New Caledonia? How can we measure the scope of political, economic, social and cultural consequences of the colonization/decolonization process? We have to rethink the impact of the colonial evidence in New Caledonia at this time of globalization and current neocolonialism forms in the Pacific. I have been asking about that for a long time and I will try to give a few replies, still partial, from my research ${ }^{4}$.

Marginalized for a long time by the colonial system, specifically by the Indigénat rule, the Kanak people have managed to survive. No doubt it was by keeping it out of the way, by the cantonment in Kanak reservations, that it could persist. If we have hardly finished putting it out of our minds, it comes back occasionally, through several famous revolts (see among others, 1858-1868, 1878, 1917). Since the Second World War, when granted French citizenship 5 , the Kanak people have burst into the Caledonian life in a more and more disturbing manner throughout the years. First, its political participation was through the Caledonian Union (UC) whose slogan was « Two Colors, One People ${ }^{6} »$. In that, the UC was way ahead of its time ${ }^{7}$.

4. For more than twenty years I have been doing research on Kanak identity and social transformations in New Caledonia and I have published various papers about it. The book Les Kanak face au développement. La voie étroite is a summary of a great part of this research (until 1993, the publication date).

5. If the article 80 of the constitution dated october 27, 1946 allows Kanak people the right of citizenship, it is only the law dated July 26, 1957 which actually gave it to all of the Kanaks, notably with the right to vote.

6. February 8, 1953 was the first apparition of the UC with this slogan for the election to the General Council (UC had won 15 seats on 25); the other slogans were «colonists and natives, join together» and «The year of the centenary would be the year of the liberation». We have to notice that until 1956, the Kanaks were more than $50 \%$ of the population of the territory and it is only in 1963 that for the first time they lost the absolute majority in the Caledonian population. The UC group has still stayed in the majority until 1973 (Rock Pidjot was reelected deputy the 11 march 1973 with $52 \%$ of the ballots). The anti-separatists had won as a matter of fact the territorial elections of 1972, further to the great immigration encouraged by the circular of the Prime Minister Pierre Messmer to his Minister of DOM-том Xavier Deniaux, dated 19 janvier 1972, who promoted «do some White» for acting against the separatist ideas of independence, only menace for «the French in Caledonia» - the UC group, in a propaganda brochure dated $1^{\text {st }}$ septembre 1971, had wrote «yes to the separation» (see Lenormand, 1991: 144).

7. The slogan of the Caledonian Union (UC) through which Kanaks first participated to the political life of their country in 1953, «Two Colors, One People» is already used by the UC movement since May 2004 for the provincial campaign (see doc. 1). 


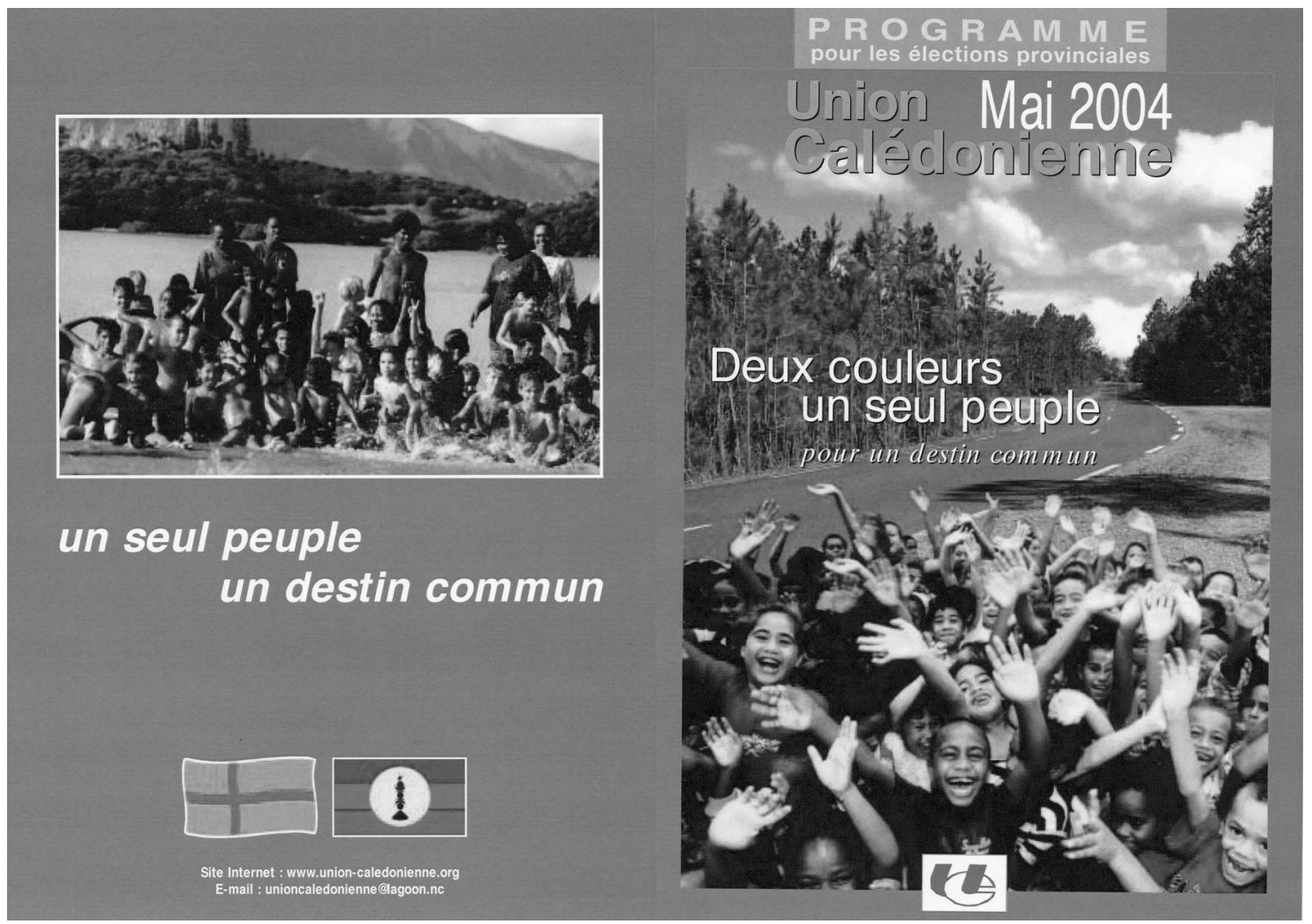

Doc. 1. - The UC program at the provincial campaign in May 2004

Furthermore, Kanak political parties and their claims progressively diversified. During the seventies, some began to speak about independance. In Novembrer 1984 and in the years after, the Kanak people have claimed strongly for it. During this time, New Caledonia was on front page of the news occasionally at the same rate as the dramatic events which shook the country. Since the Matignon agreements (June-August 1988) and the Nouméa agreement (May 1998), the situation has apparently stabilized (the $5^{\text {th }}$ May 1989 Ouvea tragedy excepted). Does that mean that Kanaks have obtained a positive response to their claims? Certainly not, but the so-called attempt at restabilization is said to be on the way, a larger autonomy of this overseas country too. As for the independance, it is postponed from one status to another. Is it still on the agenda? And what is an independant society today at time of globalization? According to Jean-Marie $\mathrm{Tjibaou}^{8}$, we must remember that independance is the ability to choose its interdependancies!
We do not claim to be dealing with all these issues here. We simply want to start up a reflection about Kanak identity in terms of "past and present dialectics», in front of the future citizenship building. In order to do that, I shall discuss first the current Kanak society, its customs which are the result - not definitive - of history and a way of openness to others, by the rule of hospitality. Then, I shall look at the way this new citizenship can be built only through the appropriation of a communal heritage - history. But this remains to be defined.

\section{Tradition and Kanak society today}

Today Kanak society is expressed by a double system of factors: the Melanesian sociocultural specificity and the Western «culture» introduced since the middle of $\mathrm{XIX}^{\text {th }}$ century. We cannot speak about Kanak identity without taking into account these two factors. It is largely in front of

8. "The sovereignty is the right to choose one's partners; independance is the power to manage all the needs created by colonization, by the system in place [...]. It is the sovereignty which gives us the rights and power to negociate the interdependancies. For such a small country as ours, independance is to calculate the interdependancies well.» (Tjibaou, 1985). 
the whole Caledonian society that the Kanak society can present itself as an entity because of its greater diversity: linguistic (twenty eight languages for ninety thousand people), sociological (social and political structures, kinship systems and the method changing in which groups are formed from one region to another) and, last of all, historical, with several regional colonial histories (a more or less colonial pressure in the mainland and in the Loyalty Islands). Hence there is a great division of sociological situations. This notion of identity refers to the social and linguistic customs, to the Kanak discourse about themselves and to their claims for identity. It is far from being an invented or reified identity.

But Kanak unity is not only a construction forcing colonization foreign pressure. Before the European arrival, it was based on an economic and kinship relations system which interconnected all the small Kanak societies. The fact of making Kanak people fringe members of society as a result of the colonization, allows them to unify in front of other social groups thanks to the appearance of forms of new solidarity and fragmentation which do not destroy the old ones. The present Kanak identity is made up as much from this diversity as from this unity, continuously reconstructed. It must be perceived as an evolution: to define this identity, it must catch the direction of this trend. If all Kanaks do not react in the same manner in regard to the changes, all share a few cultural references which make them unify, wherever they have changed according to time.

What I understand by the word tradition is that the whole Kanak social system is far from becoming ossified, but everlasting in adaptation and change. According to this conception, tradition is always evolving - before and during colonization - and will continue changing ${ }^{9}$. Use of the term «tradition» or «traditional» refers to an endogenous dynamic, its internal change, thought up by and for the Kanak people, and not imposed by the colonial rule. That leads me to point out the capacity of Kanak societies for integration and appropriation of innovation (see Leblic, 1988, 1993).

What Kanaks claim today as their «custom» or «tradition» is different from those of the precolonial time. It has changed in the one hundred and a half years of colonization: while some of its parts have carried on, others have changed. This is the result of this historical change that builds up the Kanak society and which governs the whole of Kanak practices and social relationships.

What is coming into play here in this confrontation and superimposing of the Kanak social world with the foreign parts brought by colonization, take up a «former and new dialectics»which should not be conduced with a search for lost authenticity. Such a dialectic is acting on the whole Kanak society. The «elders», through their privileged link with ancestors and spirits, are said to be the cause of predatory techniques in general. They also bring magical and propitiatory rituals linked to the yam cycle under control. All the ritual functions insuring fecondity and reproduction are related to the autochtony and the elder function (Leblic, 1999, 2000). Within this context, in the Kanak institution commonly called «chiefdom», the political and/or economic functions of a clan almost linked to ritual prerogatives, far from being hereditary, are comprehensible as the result of history. Order and conditions of settlement in the territory induce status; from the ancient-founderfirst settlers to the foreigners employed as «chief» or «servant», by way of the warriors or the messenger-mediator to the neighbouring territories, and so on, this distribution does not ignore situations of accumulation or the division of roles. Note that the first missionaries and settlers could implant themselves thanks to this Kanak ancient tradition of hospitality.

\section{Kanak Identity and Custom}

Kanak identity must be defined at several levels. First, the individual level, then the family level - its lineage, its clan -, and the relations level - uterin group and alliances -, then the region and linguistic group levels, and finally the «ethnical» level belonging to the Kanaks vis-àvis non-Kanak people.

At the individual level, several things must be considered to define the person: first his personal name duru nêe and its spirit; his surname which is also a place name and which informs about his lineage; his ancestors and totemic representa-

9. According to this statement, we can notice that the Kanaks are often very receptive to innovation. And, today many projects are bein worked on by Kanak people to allow them to experience and think diferently about their social organization, according the various imperatives of the life today. Through the PUD (plan of urbanism and development) and the PACT (plan of tribal concerted setting up) the cities must now conciliate their competences and duties with those of tribal life on «lands of custom» which do not belong to the common right. We do not have enough background about those very new questions (December 2004), but I will get back to this at another time. 
tions; his uncles; his language; and so on. All that makes him «well sitting ${ }^{10}{ }$ » as they say.

This embedding of several identity levels turns up again among others aspects in the accumulation of the various names for each person. All that sets up the Kanak custom will contribute at the others two levels.

In local French, the term «custom» touches on several notions which all derive general meaning given to this word: the oral tradional rule or the Kanak civilization, the costumary ceremonies and the gifts which are exchanged in them. We will try to make them clear from the paicî vocabulary in the way that it is used in the Ponerihouen region ${ }^{11}$.
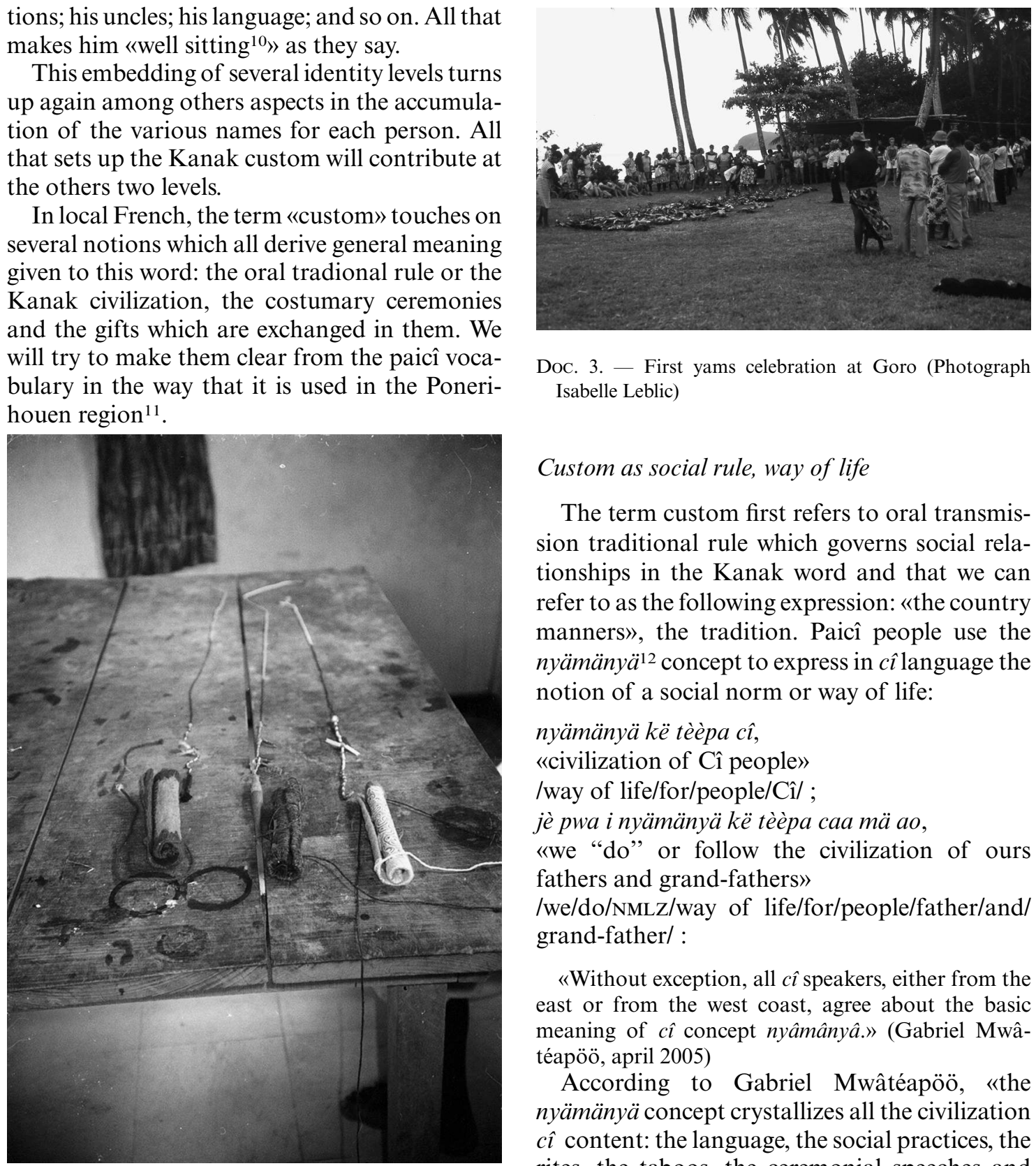

Doc. 3. - First yams celebration at Goro (Photograph Isabelle Leblic)

\section{Custom as social rule, way of life}

The term custom first refers to oral transmission traditional rule which governs social relationships in the Kanak word and that we can refer to as the following expression: «the country manners», the tradition. Paicî people use the nyämänyä ${ }^{12}$ concept to express in $c \hat{\imath}$ language the notion of a social norm or way of life:

nyämänyä kë tèèpa cî, «civilization of Cî people» /way of life/for/people/Cî/ ; jè pwa i nyämänyä kë tèèpa caa mä ao, "we "do" or follow the civilization of ours fathers and grand-fathers» /we/do/NMLz/way of life/for/people/father/and/ grand-father/ :

«Without exception, all cî speakers, either from the east or from the west coast, agree about the basic meaning of cî concept nyâmânyâ.» (Gabriel Mwâtéapöö, april 2005)

According to Gabriel Mwâtéapöö, «the nyämänyä concept crystallizes all the civilization $c \hat{\imath}$ content: the language, the social practices, the rites, the taboos, the ceremonial speeches and genealogical discourses. In short, how the $c \hat{\imath}$ civilization imagines the world, speaks of it and

Leblic)

10. So, tâa which means «to tarry, to stay» but also «family, clan», is used into several expressions like pi-tââ «family, clan» and pai-tââ «custom»/way of/so stay/.

11. Many thanks for Gabriel Mwâtéapöö who gives me in a long letter (april 14, 2005) a lot of precisions about this subject, the various meanings of the term customs and the several paicî words to answer some questions I have sent. Going further in detail I must say that when I speak about the Paicî or the Cî (or about the so-called languages), it is also those of Ponérihouen. See also for the nyämänyä concept Salomon (2000: 19-26) whose paicî quotations were translated by Gabriel Mwâtéapöö.

12. Gabriel Mwâtéapöö writes nyâmânyâ or nyêmânyê. «That is the translation word to word of these terms which all refer to the cî civilization: nyêe-mûûr $\hat{a}$ and nyêmûur $\hat{u}$ biu "the things of the past" /it is, that is/things/formely/ and /it is/things/in the past/; if the $c \hat{\imath}$ civilization is going to fly towards the futur, it comes frome the past. As it is said by the japanese proverb: "when you drink water, think to the spring"; pai pwa kë tèèpa cî̀ "the Cî own way" /way/to do/to/those/Cî/; tûa kë tèèpa cî "the Cî own

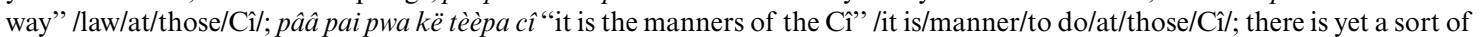
judgment in it; pai cî "the human being cî" /way, expression (verbal, gesture, behavior, cultural)/cî/» (Gabriel Mwâtéapöö, april 2005). We have to notice that this term nyämänyä means also the first ancestors, those of the beginning or «roots' ancestors» who «have bequethed so much that it is a just revulsion of things that our elders had definitly fixed their name in this concept of nyêmânyê which bears as much a resemblance to another concept as well as the globalizing concept of the meaning of civilization in French» (idem). 
practices it. I am sure that it is the evolution of each group inside of their respective spaces after the Kanak country had been divided up - notably in the fact of constraints imposed by Indigenat rule the way they were assigned to stay at home - which explains the shade of opinion in the Kanak words about nyämänyä concept». According to this meaning, each lineage has a particular inheritance, depending on its specialization. So, when we are looking for the etymology of this term, several sources are given; some of them insist on the taboo term:

«If she has inherited her Kanak mid-wife practice from her late mother Mélanie Göröèu (married to Göröcê), late gèè Agnès could only mention the taboo aspect, nyê ou nyâ as a meaning of the nyêmânyê concept, because it is this taboo which is first inherited by the clan to which she was given to become a visionary, a healer and a proclaimer of $c \hat{\imath}$ speeches.» (Gabriel Mwâtéapöö, april 2005)

Others, like Gabriel Mwâtéapöö, think about nyâ the term height:

" From the nya concept, height. It is a specific concept mainly in the field of arithmetics. Pi nyâ kâ râ nä ii ru, "they have the same height" /it is/height same/at/of/in/body/them two/; pi nyâ kâ râ pai ru, "their words have the same length", /it is/ height same/at/of/word[here]/them two/ in short they are on the same wavelength.»

This is why any informer cannot have a whole perception of its concept because he never can speak for others lineages:

«The deontology of cî nyâmânyâ is very strict: all that anyone can tell about is what he has, if he has the authority. Nobody can interfere with the inheritance of another clan, even a related one, even if they were uterin related. The $c \hat{\imath}$ good manners and savoir-faire (to which I try to conform to for certain reasons) in my humble opinion, well integrated, can impress on all persons an attitude of social respect, discretion and humility.» (Gabriel Mwâtéapöö, april 2005)

At a second level, the French word «coutume» indicates as much the act that all Kanak people perform when they arrive at somebody's place or at a particular ceremony-linked to the life cycle, to the local society or to welcoming - hence the expression "do the custom», rather than the

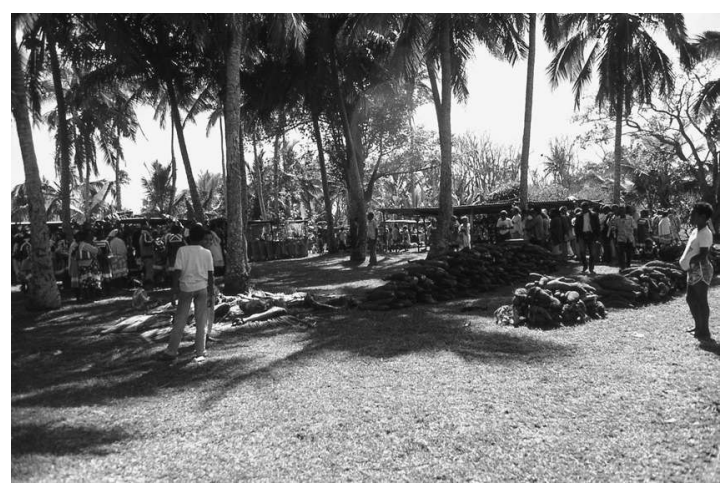

Doc. 4. - Mariage custom at Maré (August 1985) (Photograph Isabelle Leblic).

content of this act. That means giving both the presents offered on this occasion along with the speeches. Now we are going to look at the various customary ceremonies linked to the life cycle.

\section{The custom as customary ceremony}

The $c \hat{\imath}$ civilization appears through the two dimensions of life which are the visible world and the invisible one, wâro görö puu ${ }^{13}$ /life/on/earth/ and wâro jaara ité mûûrû ${ }^{14}$ /life/at/others, a part of/things/, "the life at the other things» which are the gods'ancestors (duée), the invisible protectors (apièrù)... All the human acts take place indeed in what I call in another article (Leblic, 2000) the continuum between the âji-âboro/true/human beings/, that is to say the living human beings, and the duéé, which includes as much the ancestors or deceased persons as the ancestral spirits tee commonly called «totems» in the local French and by Maurice Leenhardt -, the spirits protectors $^{15}$ apièrù and all sorts of supranatural beings, although never being living or deceased persons, who were usually considered like spirits duéé (Fig. 1).

This question of the passage or transition from the invisible world to the visible one and vice versa, «was solved by our ancestors through elements restrained in the $c \hat{\imath}$ civilization (nyämänyä cî, pai cî, tûâ kë tèèpa cî, pai para kë tèèpa $c \hat{l}) »$, by physical life management across stages which are spread out over the whole life and are marked by rites practiced to this effect, that means: birth, marriage and death. And all these

13. Görö-puu also means «the earth, the world», that implies the visible one.

14. Ité-mûkûrû or ité-mûuru means "the things from elsewhere, the spirits, the "devils"», that is to say the invisible world or what I have called elsewhere the sphere of the supranatural (Leblic, 2000).

15. Déwé Görödé explains in this terms the word apièrù: "We, morever, we do not say the deaths. We can say the others (it is a translation that I give) or those who bring up us. This term in our language is "apièru", those who take care of us, almost like guardian angels of the christian thought. They are some ancestors or deceased persons of the family. My father explains very well the roll of all this beings in his book Mon école du silence: they are averywhere, they are here, where I am sitting, perhaps they are listening me, at the moment (laughters)» (Stefanson, 1998: 79). 


\begin{tabular}{|c|c|c|c|c|}
\hline $\begin{array}{l}\text { wâro görö puu } \\
\text { human beings } \\
\text { (âji) âboro }\end{array}$ & $\leftrightarrow$ & $\begin{array}{l}\text { half-human beings, } \\
\text { half-spirits } \\
\text { tibo (u, cètuu, kapere, mäuci...) }\end{array}$ & $\longleftrightarrow$ & $\begin{array}{l}\text { wâro jaara ité mûûrû } \\
\text { supranatural beings, spirits } \\
\text { ité mûûrû or duéé } \\
\text { näpô kärä ité mûûrû = näpô } \\
\text { kärä duéé mä apièrù }\end{array}$ \\
\hline
\end{tabular}

FIG. 1. - Transition from the invisible world to the visible one by the cî civilization ( i nyämänyä cî)

customary ceremonies ${ }^{16}$, which are going to mark the stages of life are always within the context of exchanges between two groups, the patrilaterals apooro porowa /master, owner/ home/ and the maternals tèpwö/uterines, guests/, and theirs own ancestors'spirits.

\section{Custom as gift exchanged (or words said at that moment)}

The costumary act and the speech which goes with it are in fact send to the ancestors and spirits of the place where we are, or to those on the father's or mother's side related to the people for whom the ceremony is taking place, so as not to arouse the anger of the ancestors and to gain their good will. For example, the urë-pärä, «end of the trip»//end, /walk/ is the gift presented when somebody arrives at somebody else's home. It must be done as soon as one is going to visit. It has a meaning from where we leave - at home - and at where we arrive - the end of the

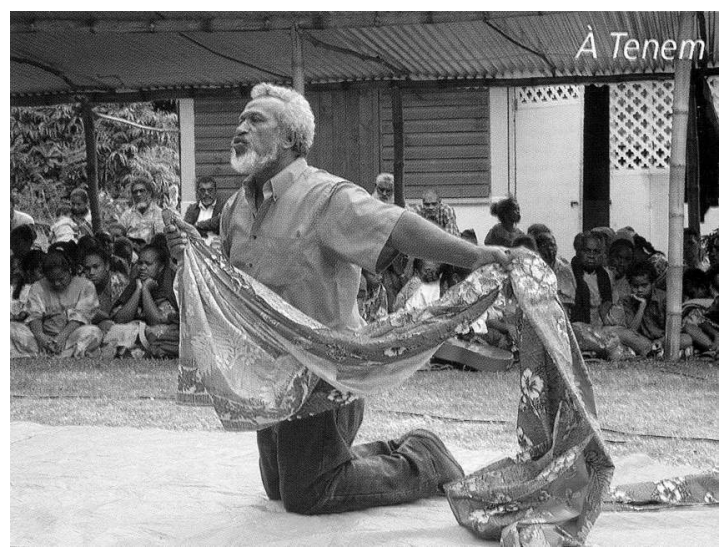

Doc. 5. - Forgiveness custom from the Wea family at Hienghène-Tenem (July 2004) (Mwâà véé 2004-2005, (C) ADCK-Centre Culturel Tjibaou, photograph Gérard Del Rio). walk -, that is somebody else's home. So it is the act of respecting the right and the people of this place. This act is made by with a $500 \mathrm{FCFP}$ note or some coins of 100 FCFP, a piece of material, a piece of tobacco, some matches and so on.

«All of this is only the material part with which the words - popai-go together to give the act a meaning. There is a territory, a field - nä-puu - which has the name of the people who welcome and this territory is inside of the invisible gate/fence - nä-babé17 /in/gate, fence/ - of the ancestors'spirits and keepers of the life - apièrù. It is this respectful possession to which the act pwö and the words popai are given - pamûâ.» (Gabriel Mwâtéapöö, April 14, 2005)

The urë pärä is not only a greeting to the hosts who receive the guests. It marks the Paicî in the visible and invisible world $c \hat{\imath}$. In the past, this $p w \ddot{o}$ - act - was carried out by the host on the altar of the ancestors'spirits for being placed or tied on it - pi-pwö. In others words, this act is performed in order that the spirit ancestors of the place can exert both their welcoming right to the people who arrive and their duty of protection during their stay in this place. We do not forget that arriving people are coming together with their invisible spirits ancestors: «their own and those of their uterins». The aim of the urë pärä is also to ensure that all the spirits ancestors can have harmonious relationships. As we have written (Leblic, 2003), all meetings whether religious or political begin with the presentation of this urë pärä by the arriving delegations.

\section{Custom and independentist claims}

The custom, or what is said in the local French «la coutume», touches all the social rules of the Kanak society. It is sure that this custom is used as a cement, a support for the source of the

16. I twill be too long to detail it in this article. For more details, see Leblic (in press).

17. In the ceremonial speeches, one says «baa-gë mä wéaa-gë, your wall and your protection: your reserves for facing with your customary obligations» (Rivierre, $1983: 41$ ), from $b a$, wall and wéaa, protection, fence. 
Kanak nationalism, without speaking of traditionalism. The first claim, at the end of the Indigénat rule, was to recognize the Kanak specificity, as the Mélanésia 2000 Festival put on by Jean-Marie Tjibaou in 1975 (Tjibaou and al., 1976) showed us. Then, it became a claim for independence.

In the seventies, the independence claim was already so political for some as the Groupe 1878 and the Foulards Rouges (Red Scarves) which prefigured the PALIKA, but for others was presented in more cultural terms, notably for the majority of Kanaks who do not have any responsibilities in any political union. But can we separate in this sense the «cultural» from the «political»?

During the events of 1984 , the independence claim was strongly based on «the custom». No political meeting, no step was taken without a customary exchange of gift. In 1985-1986, it was always with this help and support of the Kanak custom as the foundation of the forthcoming independent society that allowed, among other things, the boycott of liquor, of sports, of colonial schools and all the non local products within the context of the claim of economic selfsufficiency. It was also the period of the expansion of the EPK (Kanak popular schools) that had put all those principles into practice and that had based a great part of the teaching on those of «the custom».

The 1988 and 1989 events had marked a break. First, with the assassination of the nineteen Kanaks in the Watetö cave in Ouvéa by the French army, on May $5^{\text {th }} 1988$. Then, with the signing of the Matignon agreements (in June
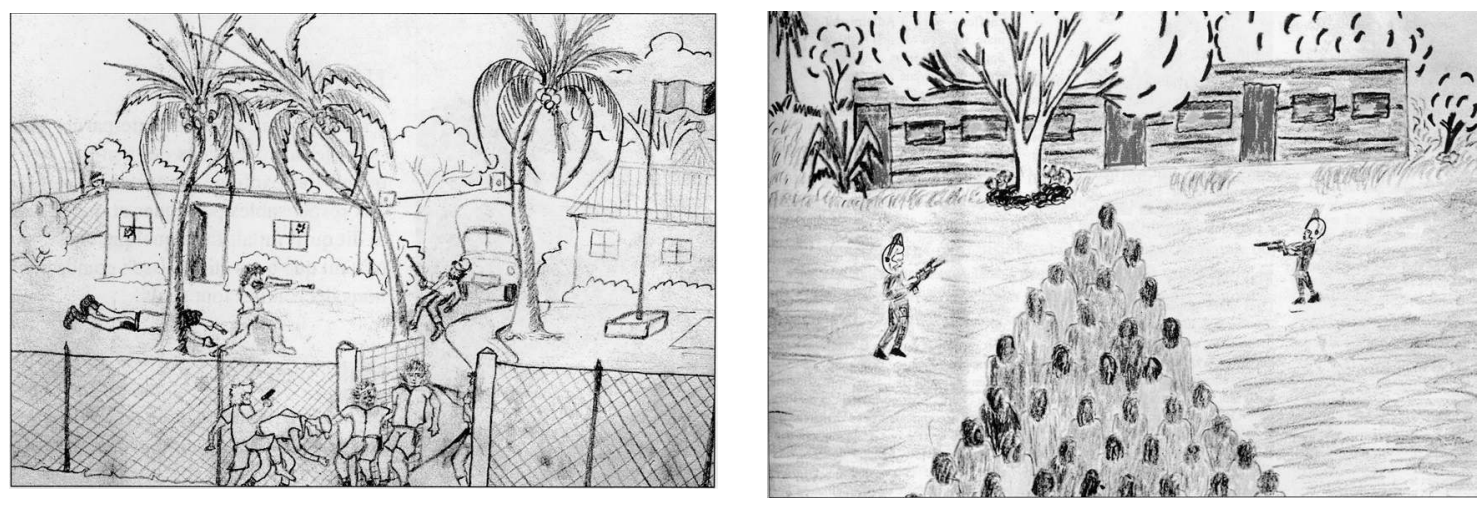

Doc. 6-7. - Uvean Children drafts about the 1988 events at Uvea (Mwà véé, 1999 : 43 et 57)

(C) ADCK-Centre Culturel Tjibaou, phothographs Jean-François Marin)

and August 1988). And, above all, a year later (May $5^{\text {th }} 1989$ ), the assassination of Jean-Marie Tjibaou, Yeiwéné Yeiwéné and consequently of Jubelly Wéa during the celebration of the end of mourning for the Nineteen, deeply left its mark on everybody's mind and have induced a trauma that the Kanak people had a lot of trouble recovering from. Can we also interpret the murder of the two Kanak leaders by resorting to «the custom»? Wasn't it certain, in some people's minds, a revenge for the last year blooding events and for which no act had been undertaken? Somebody said this at this time. The manner even - an ambush during a costumary ceremony - must be considered as much as traditional ; the oral litterature has cases of such attack stories.

Since Ouvea, the independentist mouvement has crossed a crisis which it is hard to outdo. This deeply political crisis must sometimes involve a withdrawal into tradition. It would be too long to give here some examples of such withdrawal; we may only say that it takes often the forms of accusations of sorcery and of all sorts of sorcery trials. It is not the first time this has happened this way. Other social crises like that have already occurred at Ponerihouen.

\section{The ceremonies of reconciliation}

To conclude on this subject, I will simply mention the ceremony of reconciliation which had took place last July (2004) between the Tjibaou and Fisdiépas families (Hienghène), the Yeiwéné 
family (Maré) and the Wéa family ${ }^{18}$ (Ouvéa), largely initiated by the children of the deceased, outside of any political context, but on the customary field, following the roads successively in the three concerned places.

Supported by the clans related and by the Churches, it was a private initiative between the four families concerned by the drama, apart from the political parties. The ceremonies were the occasion to exchange between the four families informations about the drama. For example, Marie-Claude Tjibaou has said that it is the first time she heard that her husband was murdered inside the chiefdom fence in Hwadrilla. All the families had insisted on their feeling of isolation since the dramas of 1988-1989. Since last year (2004), they said they felt delivered! The three mothers, Marie-Claude Tjibaou, Hnadruné Yeiwéné and Manaki Wéa, said they have made this reconciliation, first for and with their children, and after for their country.

At each place, they put a commemorative plaque and they plant trees for not forget these events. And in Uvéa, they planted trees where the blood flewed... The uncles of the deceased were here for getting back the blood.

To conclude, what is at stake now, according to me, it is not to find the right version of the past, but a shared history. Kanak and Caledonian Peoples have to build and to appropriate a common history for building the future citizenship.

And the reconciliation made by the Tjibaou, Yeiwéné and Wéa families is in this sense a lesson for all the inhabitants of New Caledonia. We shall hope that this reconciliation could be a model for others. A common history shared by Kanak and Caldoches is also a way of global reconcilation.

\section{Kanak Identity and Kanak people : the Kanaky flag and the flnks constitution}

We celebrated the same year (2004) the twentwieth anniversary of the first flying of the Kanaky flag at La Conception by Jean-Marie Tjibaou on December $1^{\text {st }}$ 1984. It accompanied the formation of the FLNKS shadow cabinet whose first president had been Jean-Marie Tjibaou. The Kanaky flag is very symbolic of the claims for Kanak identity. It consists of three horizontal strips, from the bottom to the top: green for the earth of the ancestors, the wealth of the ground, the hope and the country; red for the blood pouring during the fight for independence, the socialism and the unity of the people; blue for the sky and the Pacific ocean, and, in the middle, a yellow sun which has at its centre a dark roof shaft with a conch - Charonia (charonia) tritonis Linné -, like those which are on the top of the Kanak huts. All symbolise «the Kanak sovereignty of the Kanak country in the Pacific ocean» (Kurtovitch, 2003 : 264).

The constitution, drawn up in those days for an independent Kanaky, stresses the elements making up the Kanak identity:

«We the Kanak people, proud of our past and our ancestors who protested against oppression and gave their blood for the struggle for liberty, deeply attached to our traditions, setting up a free, united and sovereign national community, based on the solidarity of the elements of various origins which form it, we solemnly affirm that our custom expresses our main cutlural values that are the basis for our social life; we also affirm that the clan, the organic element of the Kanak society, is the traditional owner of the lands according to the customary rules and in respect for the nation's own good; we set up the Kanak state which is a secular socio-democratic republic, where the national sovereignty belongs to the people who vote for it. The Custom works towards the expression of the popular sovereignty; we declare our support for the universal Declaration of the Rights of Man dated December 10, 1948 and we guarantee the respect for individual and common liberties, the right to strike and union rights. Nobody can be subjected to the death penalty; we declare our support to the Charter of the United Nations and we affirm that we shall spare no effort to reinforce the solidarity between the people and the states of the Pacific, and to cooperate on with all the nations; we affirm our refusal of nuclear weapons. This preamble has constitutional value.» (FLNSK, 1987)

\section{And its first article points out:}

«The Kanak people are a free, unified and sovereign national and pluriethnic community, based on the solidarity of its elements. [...] The national emblem is the flag made of three horizontal strips [...]» (FLNKS, 1987)

Thus the notion of Kanak people, making up the future nation Kanaky, is applied to all the citizens of this country, whatever their ethnic origin. According to this definition, the citizens of Kanaky would all be people who choose to live in this country and to take on its nationality as defined by the constitution. But this is only a project!

The most recent text which governs New Caledonia is that of the Nouméa agreement in where,

18. Apart from the family of Jean-Marie, Yéiwéné and Djubelli, there is also the one of the bodyguard of Jean-Marie, Daniel Fisdiépas, who replied the first murders by killing Djubelly. 
in the preamble, «victims of history» are no longer mentioned as they had been at Nainvillesles-Roches but communities which have gained a legitimacy to live in this country according to their Kanak identity:

«The communities who live in the territory, who have contributed to the building of New Caledonia, have acquired a legitimacy to live here and to go on contributing to its development. [...] Today it is necessary to set the foundations for the New Caledonian citizenship, allowing to the original people to constitute, with the men and women that live in it, a human community of shared destiny. [...] Ten years after [the Matignon agreements], it is advisable to open a new step, marked by the deep recognition of the Kanak identity, preliminary to the refoundation of a social contract between all the communities living in New Caledonia and with a joint sovereignty with France, on the way towards complete sovereignty. The past was the time of the colonization. The present is the one of the sharing through reequilibriating. The future must be the time of identity in a common destiny.»

\section{A common history to build and to appropriate}

During a long period, the Europeans of New Caledonia had hidden an entire part of their local history, especially that of imprisonment, not to mention that many are deceased from the first arrivals in New Caledonia - that is convicts $^{19}$. This tendancy has been reversed in the last few years. It is the consequence of independentist demands that a few "progressive» Caldoches have begun to think about their «roots» and their identity as Caldoches. The Kanaks, on their side, do not have a written history as their languages are not written. The transmission of their varied heritage was made only orally (Leblic, 2004). If ethnohistory can restore history for a society without writing and written archives ${ }^{20}$, it is true that it gives us history «reproduced according to a temporality often out of sync, avoiding all chronology» (Frimigacci and Vienne, 2001: 6). But it still is the only way to reconstitute a local history. Along with Bernard Vienne and Daniel Frimigacci, we will say that:

«The first vocation of the oral tradition is not to transmit the history of a group but rather the legitimity of a set of prerogatives, rights and obligation, rooted in a system of values, in a recognized identity.» (Frimigacci and Vienne, 2001: 6)
Yet, as our field researches show, we are often faced with a multitude of identities, which change from one informer to the next, because we have always a great variety of versions for the same oral tradition, each one aiming to justify some particular rights. How within this context can we write the history of the Kanak societies?

«Oral tradition, this mark of the past which persists in the present, is only transmitted and kept alive because it is accepted as a referent from those who receive it. This is why it has a potential historical value; a sort of transmutation must still be performed [...] to produce with it the document "from oral archives", the historical document.» (Frimigacci and Vienne, 2001: 6).

And it is precisely this shared acceptance by sufficiently large set of people than can allow establishing a local history which often poses problems, we must not forget that the notion of linear chronology, necessary to history, is often missing.

If the genealogies offer us a linear time through the succession of generations, oral history reminds us of the events outside of all chronology, events which are not precisely datable. The cross of genealogical facts and oral history allows us a certain approximation of estimate chronology, at the very most for the two last centuries. And here we can cross some data with the written archives of the colonial period. For the most ancient time is possible the use of archeological digs to determine and date some tracks of ancient settlements. No doubt it will not be enough to reconstruct the history of the Kanak country of former times.

Some, like Christophe Sand and al. (2003) who are focussing on the fact «that the use of archeological data could be, not a source of divisions, but a footbridge for sharing common cultural and historical referents, within "the creation of a community of unanimous destiny" of the Nouméa agreement, signed in 1998» (p. 149). They also deal with the to talk about «our ancestors the Lapita» in place of «our ancestors the Gaulois» taught to generations of Caledonians, all ethnic groups combined. Whatever the unanimous patrimony constructed for everybody's appropriation, it seems important today that a collective reflection should take place on a local level to determine which history must be handed down to the children of this country. First we must find an agreement for a presentation of the

19. See the book of Louis-José Barbançon (1992) rightly entitled Le pays du non-dit !

20. We must note that if we have, for a long time, opposed the societies which have a written history to those of oral transmission, often said to be without history, this dichotomy is already outdated. All human society is historical, whether it has writing or not. 
local microhistories. Then, with the addition of several local histories, we can build up a global history of the Kanak country. This one, added to the «colonial» history would allow the elaboration of a common and shared historical patrimony. This is actually what is at stake for the future New Caledonia.

\section{Thanks}

Many thanks for the inhabitants of Ponérihouen, and specially for Gaby Mwâtéapöö. And for the Tjibaou cultural center which allows me to reproduce pictures of the ceremonies of reconciliation published in Mwà vèè 46-47, 20042005: 17 juillet-8 août 2004, Pardon et réconci-

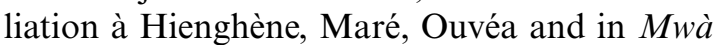
vè̀ 25, 1999: Usooköu Ouvéa. Le temps de la réconciliation.

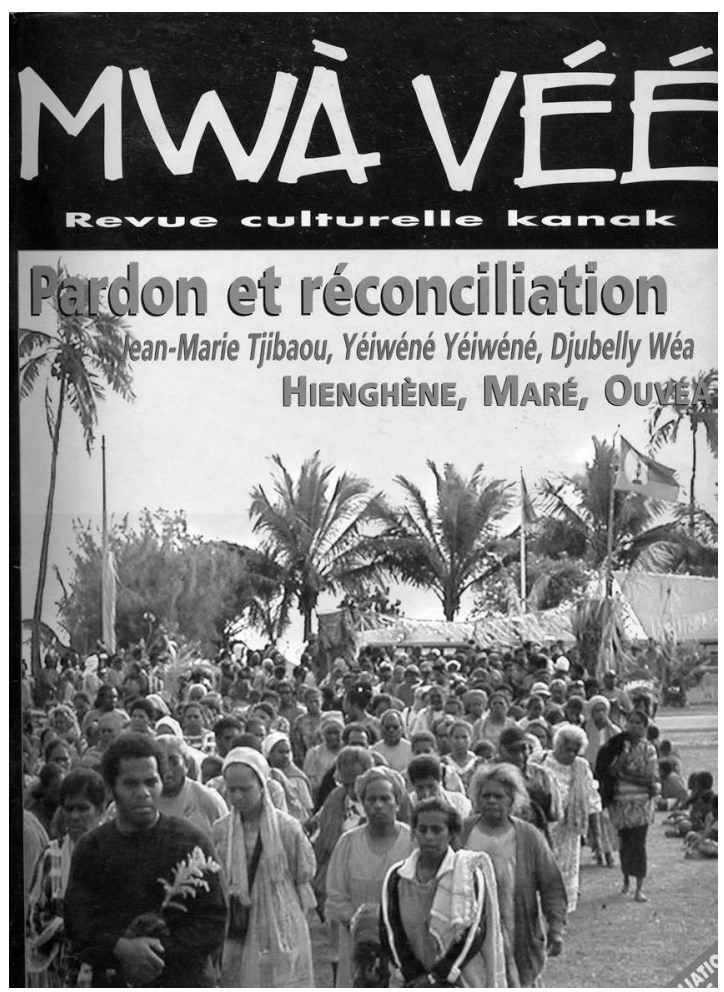

Doc. 8. - Front page of Mwà vèè 46-47, 2004-2005 (C) ADCK-Centre Culturel Tjibaou, photograph Gérard Del Rio).

\section{BIBLIOGRAPHY}

BARBANÇON Louis-José, 1992. Le pays du non-dit, La Mothe-Achard, Offset Cinq Édition.

Frimigacci Daniel et Bernard VIENNE, 2001. Wallis Futuna. 3000 ans d'histoire, Nouméa, association de la jeunesse wallisienne et futunienne en NouvelleCalédonie, IRD, 64 p.

Front de libération national Kanak socialiste, 1987 (19 janvier). Projet de constitution, Nouméa, document FLNKS, 16 p. ( http://www.kanaky.or/lekanak/ flnks/constitution/ constitution .htm.)

Kurtovitch Ismet, 2003. Éléments pour une chronologie des «événements 》 en Nouvelle-Calédonie (1981-1988), François Mitterrand et les territoires français du Pacifique (1981-1988). Mutations, drames et recompositions; enjeux internationaux et franco-français, Jean-Marc Regnault (éd.), Les Indes savantes, Paris, pp. 259-268.

LEBLIC Isabelle, 1988. L'évolution des techniques de pêche en Nouvelle-Calédonie, Techniques \& Culture 12, juillet-décembre, CNRS, Paris, pp. 81-119.

_, 1993. Les Kanak face au développement. La voie étroite, Grenoble, Presses universitaires de Grenoble, $412 \mathrm{p}$.

_, 1999. Marmites rituelles et autochtonie à Ponérihouen (Vallées de Göièta-Näbai, NouvelleCalédonie), Techniques \& culture 33, CNRs, Paris, 1999, pp. 53-87.

—, 2000. Diables et « choses d'ailleurs » à Ponérihouen (Nouvelle-Calédonie), «Diable $(s) »$, Cahiers de littérature orale 48, Publications Langues'O, Paris, pp. 203-230.

—, 2003. De la démocratie à la base : coutume et militantisme Kanak dans les années 1985-1986, suivi de la généalogie du paysage politique en Nouvelle-Calédonie (1946-1988), François Mitterrand et les territoires français du Pacifique (19811988). Mutations, drames et recompositions ; enjeux internationaux et franco-français, Jean-Marc Regnault (éd.), Les Indes savantes, Paris, pp. 311 317 et pp. 318-319.

_, 2004. Présentation, JSO 117, Nouvelle-Calédonie, 150 ans après la prise de possession, 2003-2, pp. 135145.

—, 2004b. Tradition orale et micro-histoire locale à Ponérihouen. Les difficultés d'une enquête et de son rendu, communication à la $\mathrm{XVI}^{\mathrm{e}}$ conférence de la Pacific History Association (PHA) à Koné le 10 décembre 2004 (à paraître).

—, 2007 (sous presse). Identité kanak et citoyenneté de demain, in Bernard Rigo (éd.), L'Outre-mer et la mondialisation. Enjeux et stratégies culturelles en Polynésie française et en Nouvelle-Calédonie, Paris, Éditions du CNRS, coll. Communications, $10 \mathrm{p}$.

—, à paraître. "Échanger dans la route» ou «suivre le chemin du sang». Étude de la parenté paicî à Ponérihouen (Nouvelle-Calédonie), 180 p. 
LeBLIC Isabelle (éd.), 2003. Nouvelle-Calédonie 150 ans après la prise de possession, JSO 117, $210 \mathrm{p}$.

LENORMAND Maurice H., 1991. Décolonisation ratéeindépendance avortée, Une décennie de changements, JSO 92-93, pp. 141-155.

SAND Christophe, Jacques Bolé et André Ouetcho, 2003. Les aléas de la construction identitaire multi- ethnique en Nouvelle-Calédonie : quel passé pour un avenir commun ?, JSO 117, pp. 147-169.

SteFAnson Blandine, 1998. Entretien avec Déwé Gorodé, Notre Librairie. Revue des littératures du Sud: Littérature de Nouvelle-Calédonie 134, pp. 7586.

Tüibaou Jean-Marie, 1985. Entretien avec Jean-Marie Tjibaou, Les Temps modernes 464, pp. 1587-1601. 